\title{
Pengaruh Produk Domestik Regional Bruto (PDRB) Daerah Terhadap Pertumbuhan Ekonomi dan Tingkat Pengangguran Terbuka di Provinsi DKI Jakarta
}

\author{
Putri Romhadhoni, Dita Zamrotul Faizah, Nada Afifah \\ Departemen Matematika, Fakultas MIPA, Universitas Padjadjaran \\ putriromhadhoni98@gmail.com, dt.faizah@gmail.com, nadaafifah28@gmail.com
}

\begin{abstract}
Abstrak
Pengangguran merupakan penduduk usia kerja yang tidak memiliki pekerjaan untuk memenuhi kebutuhan hidup. Tingkat pengangguran terbuka yang tinggi merupakan masalah serius yang dapat memberikan dampak buruk terhadap pertumbuhan ekonomi dan juga kesejahteraan masyarakat. Pertumbuhan ekonomi merupakan indikator penting dalam menilai kinerja perekonomian suatu negara atau daerah. Penelitian ini bertujuan untuk menganalisis pengaruh PDRB (Produk Domestrik Regional Bruto) daerah terhadap pertumbuhan ekonomi dan tingkat pengangguran terbuka di Provinsi DKI Jakarta secara langsung dan tidak langsung yang mana kelak dapat membantu pengambil kebijakan dalam mengambil kebijakan yang tepat untuk perekonomian Provinsi DKI Jakarta. PDRB dibagi menjadi dua macam yaitu PDRB atas harga konstan dan PDRB atas dasar harga berlaku. Data yang digunakan dalam penelitian adalah data sekunder, menggunakan teknik analisis jalur (path analysis). Hasil analisis data menunjukkan, PDRB atas harga konstan berpengaruh positif terhadap pertumbuhan ekonomi dan tidak berpengaruh terhadap tingkat pengangguran terbuka. PDRB atas dasar harga berlaku tidak berpengaruh terhadap pertumbuhan ekonomi dan tingkat pengangguran terbuka. Pertumbuhan ekonomi berpengaruh positif terhadap tingkat pengangguran terbuka. Pertumbuhan ekonomi bukan merupakan variabel mediasi dalam PDRB harga konstan dan PDRB atas dasar harga berlaku terhadap tingkat pengangguran terbuka. Kata kunci: PDRB atas dasar harga konstan, PDRB atas dasar harga berlaku, pertumbuhan ekonomi, tingkat pengangguran.
\end{abstract}

2000 Mathematics Subject Classification: 62J05 Received: 2018-11-09, accepted: 2018-12-13. 


\begin{abstract}
Unemployment is defined as a working age population who dont have a job to fulfill their life necessities. The high number of open unemployment is a serious problem and has negative impact on economic growth and social welfare. Economic growth is an important indicator to evaluate economic performance of a country or a region. This study attempts to analyze the influence of the regional GRDP on economic growth and open unemployment rate in jakarta directly and indirectly which will help decision makers in taking the right policy to the economy of the capital city. There are two kinds of GRDP, GRDP over the constant prices and GRDP on the basis of the current prices. The data used in this study are secondary data, using the technique of path analysis (path analysis). The results showed that GRDP at constant prices has a positive effect on economic growth and does not affect the open unemployment rate. GRDP at current market prices does not have a significant effect on economic growth and does not affect the open unemployment rate. Economic growth have a significant effect on the open unemployment rate. Economic growth is not a mediating variables in GRDP at constant prices and GRDP at current market prices on the open unemployment rate.

Keywords :The GRDP on the constant prices, GRDP on the basis of current prices, economic growth, open unemployment rate.
\end{abstract}

\title{
1. Pendahuluan
}

Di era ekonomi modern saat ini, telah terbukti secara empiris bahwa mekanisme pasar tidak dapat berjalan sendiri tanpa peran pemerintah untuk mencapai kondisi perekonomian yang optimal. Kondisi ini memberikan legitimasi bagi pemerintah untuk mengambil peran yang lebih banyak dalam membuat kebijakan ekonomi agar manfaat dari perekonomian dapat dirasakan oleh seluruh komponen masyarakat.

Pembangunan sendiri dilaksanakan mewujudkan kemakmuran masyarakat melalui pengembangan perekonomian mengatasi berbagai permasalahan pembangunan dan sosial kemasyarakatan seperti pengangguran dan kemiskinan. Selain pertumbuhan ekonomi, salah satu aspek penting untuk melihat kinerja pembangunan adalah seberapa efektif penggunaan sumber-sumber daya yang ada sehingga lapangan kerja dapat menyerap angkatan kerja yang tersedia. Pertumbuhan ekonomi sendiri merupakan indikator penting dalam menilai kinerja perekonomian suatu negara atau daerah.

Salah satu indikator keberhasilan pelaksanaan pembangunan yang dapat dijadikan tolok ukur secara makro adalah pertumbuhan ekonomi yang dicerminkan dari perubahan PDRB (Produk Domestik Regional Bruto) dalam suatu daerah. PDRB didefinisikan sebagai jumlah nilai tambah yang dihasilkan oleh seluruh unit usaha dalam suatu wilayah, atau merupakan jumlah seluruh nilai barang dan jasa akhir yang di hasilkan oleh seluruh unit ekonomi di suatu wilayah. Semakin tinggi pertumbuhan ekonomi suatu wilayah menandakan semakin baik kegiatan ekonomi daerah. Pertumbuhan ekonomi daerah tersebut ditunjukkan dari laju pertumbuhan PDRB atas dasar harga konstan (Todaro \& Smith, 2008).Dengan pertumbuhan ekonomi yang semakin meningkat berarti produksi dari jenis jasa maupun barang yang dihasilkan juga meningkat, dapat menyerap tenaga kerja dalam jumlah banyak. Sehingga pengangguran berkurang dan kemiskinan yang semakin menurun.

Pemerintah melalui Sistem Perencanaan Pembangunan Nasional mengatakan bahwa bahwa perencanaan pembangunan nasional maupun regional merupakan kegiatan yang berlangsung 
terus menerus dan berkesinambungan mengikuti pola tertentu berdasar hasil kajian yang cermat terhadap situasi dan kondisi bagus. Pembangunan yang bersifat menyeluruh dan tuntas perlu dilakukan, sehingga sasaran pembangunan yang optimal dapat tercapai. Akan tetapi, kemampuan setiap daerah dalam pembangunan berbeda-beda, karena dipengaruhi oleh pengaruh baik secara langsung maupun tidak langsung. perencanaan pembangunan nasional maupun regional merupakan kegiatan yang berlangsung terus menerus dan berkesinambungan mengikuti pola tertentu berdasar hasil kajian yang cermat terhadap situasi dan kondisi bagus. Pembangunan yang bersifat menyeluruh dan tuntas perlu dilakukan, sehingga sasaran pembangunan yang optimal dapat tercapai. Oleh kerena itu, penelitian ini membahas tentang analisis pengaruh PDRB (Produk Domestrik Regional Bruto) daerah terhadap pertumbuhan ekonomi dan tingkat pengangguran terbuka di Provinsi DKI Jakarta. PDRB sendiri dipilih dikarenakan pertumbuhan ekonomi sendiri merupakan perkembangan kegiatan dalam perekonomian yang menyebabkan barang dan jasa yang diproduksikan dalam masyarakat bertambah dapat diukur melalui perkembangan PDRB suatu tahun dengan tahun sebelumnya yang dinyatakan dalam satuan persen. Adapun data yang digunakan dalam penelitian adalah data sekunder, menggunakan teknik analisis jalur (path analysis).

Beberapa penelitian sebelumnya, beberapa penelitian berfungsi untuk analisa dan memerkaya pembahasan penelitian, diantaranya Hamzah Ardi yang membahas mengenai Analisis Pengaruh PAD, DAU, DAK, dan Belanja Pembangunan terhadap Pertumbuhan Ekonomi,Kemiskinan, dan Pengangguran:Pendekatan Analisis Jalur, Alghofari yang membahas mengenai Analisis Tingkat Pengangguran di Indonesia Tahun 1980-2007, Agustin yang membahas mengenai Pengaruh Langsung dan Tidak Langsung Biaya Perawatan, Fasilitas, Lokasi dan Pelayanan terhadap Loyalitas Melalui Kepuasan Pasien, Kurniawan, yang membahas mengenai Analisis PDRB, UMK, dan Inflasi terhadap Tingkat Pengangguran Terbuka di Kota Malang Tahun 1980-2011, Himawan yang membahas mengenai Pengaruh Produk Domestik Regional Bruto (PDRB) terhadap Tingkat Kemiskinan di Kota Manado (Tahun 2005-2014), dan yang terbaru Parwata pada tahun 2016 yang membahas mengenai Pengaruh Produk Domestik Regional Bruto (PDRB) dan Tingkat Pengangguran Terbuka terhadap Tingkat Kemiskinan. Adapun yang membedakan penelitian ini dengan penelitian yang sebelumnya adalah mengenai analisis yang di ambil merupakan pengaruh antara Produk Domestik Regional Bruto (PDRB) daerah terhadap pertumbuhan ekonomi dan tingkat pengangguran terbuka di Provinsi DKI Jakarta. Adapun penelitian ini bertujuan untuk menganalisis pengaruh PDRB (Produk Domestrik Regional Bruto) daerah terhadap pertumbuhan ekonomi dan tingkat pengangguran terbuka di Provinsi DKI Jakarta secara langsung dan tidak langsung yang mana kelak dapat membantu pengambil kebijakan dalam mengambil kebijakan yang tepat untuk perekonomian Provinsi DKI Jakarta.

\section{Metode Penelitian}

2.1. Rancangan Penelitian. Penelitian ini dirancang untuk mengetahui pengaruh langsung Produk Domestik Regional Bruto (PDRB) yang terdiri dari PDRB atas harga konstan dan PDRB atas dasar harga berlaku terhadap pertumbuhan ekonomi dan tingkat pengangguran terbuka di Provinsi DKI Jakarta serta pengaruh tidak langsung PDRB atas harga konstan dan PDRB atas dasar harga berlaku terhadap pertumbuhan ekonomi dan tingkat pengangguran terbuka di Provinsi DKI Jakarta, dengan metode analisis jalur (path analysis).

2.2. Jenis dan Sumber Data. Data yang digunakan dalam penelitian adalah data sekunder. Data sekunder adalah sumber data yang tidak langsung memberikan data kepada pengumpul data (Sugiono:2008:402). Data diperoleh dari Publikasi Badan Pusat Statistik (BPS) Provinsi DKI Jakarta berupa Produk Domestik Regional Bruto Atas Dasar Harga Konstan Menurut Kabupaten/Kota Adm, Produk Domestik Regional Bruto Atas Dasar Harga Berlaku Menurut Kabupaten/Kota Adm, Tingkat pengangguran terbuka Terbuka Kabupaten/Kota, dan Pertumbuhan Ekonomi Kabupaten/Kota di Provinsi DKI JakartaTahun 2013-2015. 
2.3. Definisi Operasional Variabel. Definisi operasional variabel yang digunakan dalam penelitian ini dapat dijelaskan sebagai berikut:

(1) Produk Domestik Regional Bruto (PDRB)

PDRB didefinisikan sebagai jumlah nilai tambah yang dihasilkan oleh seluruh unit usaha dalam suatu wilayah, atau merupakan jumlah seluruh nilai barang dan jasa akhir yang di hasilkan oleh seluruh unit ekonomi di suatu wilayah. Semakin tinggi pertumbuhan ekonomi suatu wilayah menandakan semakin baik kegiatan ekonomi daerah. Pertumbuhan ekonomi daerah tersebut ditunjukkan dari laju pertumbuhan PDRB atas dasar harga konstan (Todaro dan Smith, 2008).

(2) Pertumbuhan Ekonomi

Pertumbuhan ekonomi adalah kenaikan kapasitas dalam jangka panjang dari negara yang bersangkutan untuk menyediakan berbagai barang ekonomi kepada penduduknya yang ditentukan oleh adanya kemajuan atau penyesuaian teknologi, institusional (kelembagaan), dan ideologis terhadap berbagai tuntutan keadaan yang ada (Kuznetz dalam Todaro, 2004).

(3) Tingkat pengangguran terbuka

Pengangguran terbuka (open unemployment) atau secara umum pengangguran adalah penduduk berusia kerja yang tidak mempunyai pekerjaan apapun yang secara aktif mencari pekerjaan. (Abdul Hakim dalam Ekonomi Pembangunan, 2010)

2.4. Teknis Analisis Data. Penelitian ini menggunakan pendekatan yang bersifat kuantitatif. Variabel terikat dalam penelitan ini adalah pertumbuhan ekonomi dan tingkat pengangguran terbuka terbuka. Sedangkan, variabel bebas dalam penelitian ini adalah Produk Domestik Regional Bruto (PDRB). Teknis analisis data yang digunakan adalah teknis analisis jalur (path analysis). Kerlliner (2002) menyebutkan bahwa dengan menggunakan analisis jalur akan dapat dihitung pengaruh langsung dan tidak langsung antar variabel. Uji yang digunakan untuk mengetahui pengaruh langsung antar variabel yaitu uji $\mathrm{T}$. Uji yang digunakan untuk mengetahui pengaruh tidak langsung antara PDRB terhadap tingkat pengangguran terbuka dengan variabel mediasi pertumbuhan ekonomi yaitu sobel test. Hubungan antarvariabel penelitian ditampilkan pada Gambar 1. Berdasarkan Gambar 1 dapat dibuat persamaan struktural, yaitu:

$$
\begin{gathered}
\hat{Y}_{1}=\beta_{1} X_{1}+\beta_{2} X_{2}+e_{1} \\
\hat{Y}_{2}=\beta_{3} X_{1}+\beta_{4} X_{2}+\beta_{5} Y_{1}+e_{2}
\end{gathered}
$$

Model tersebut dikembangkan untuk menjawab permasalahan penelitian serta berbasis teori dan konsep, yang dapat diilustrasikan seperti gambar 1.

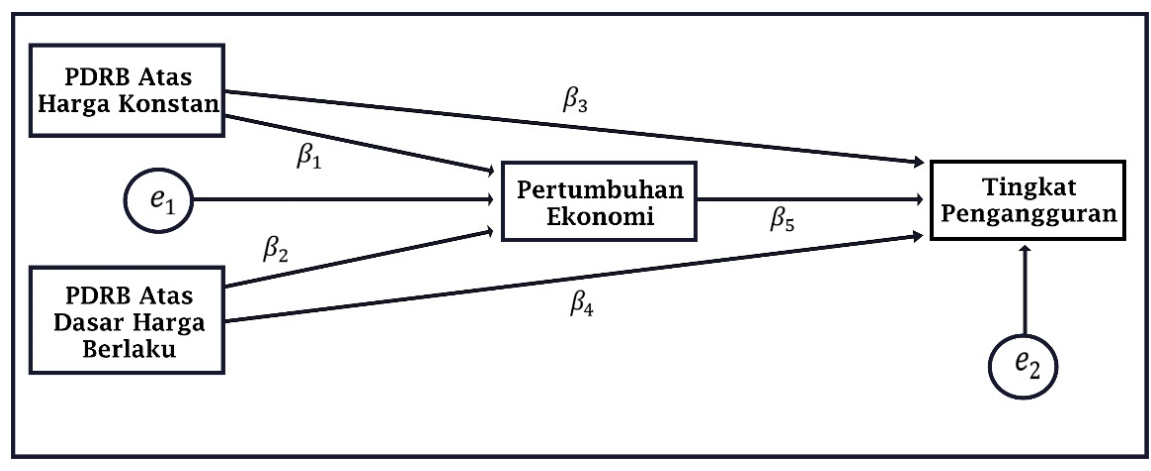

Gambar 1. Diagram jalur variabel penelitian 


\section{Hasil Dan Pembahasan}

Penelitian ini dilakukan untuk menganalisis pengaruh PDRB atas harga konstan dan PDRB atas dasar harga berlaku terhadap pertumbuhan ekonomi dan tingkat pengangguran terbuka terbuka. Dalam, penelitian ini digunakan teknik analisis jalur (path analysis). Path analysis dilakukan dengan menggunakan software SPSS versi 23, dan hasilnya secara lengkap disajikan pada Tabel 1. Untuk penyelesaian analisis jalur maka perlu mengetahui adanya path diagram maupun path coefficients (koefisien jalur). Maka analisi jalur disajikan pada Gambar 2 .

Tabel 1. Ringkasan Koefisien Jalur

\begin{tabular}{|c|c|c|c|c|}
\hline Regresi & Koef. Regresi Standar & Sig & T hitung & Keterangan \\
\hline$X_{1} \rightarrow Y_{1}$ & 2,124 & 0,044 & 3,335 & Signifikan \\
\hline$X_{2} \rightarrow Y_{1}$ & $-1,199$ & 0,079 & $-1,882$ & Tidak signifikan \\
\hline$X_{1} \rightarrow Y_{2}$ & 1,098 & 0,523 & 0,656 & Tidak signifikan \\
\hline$X_{2} \rightarrow Y_{2}$ & $-1,802$ & 0,222 & $-1,277$ & Tidak signifikan \\
\hline$Y_{1} \rightarrow Y_{2}$ & 1,290 & 0,025 & 2,507 & Signifikan \\
\hline
\end{tabular}

Error $\left(e_{1}\right)=0,319$

Error $\left(e_{2}\right)=0,613$

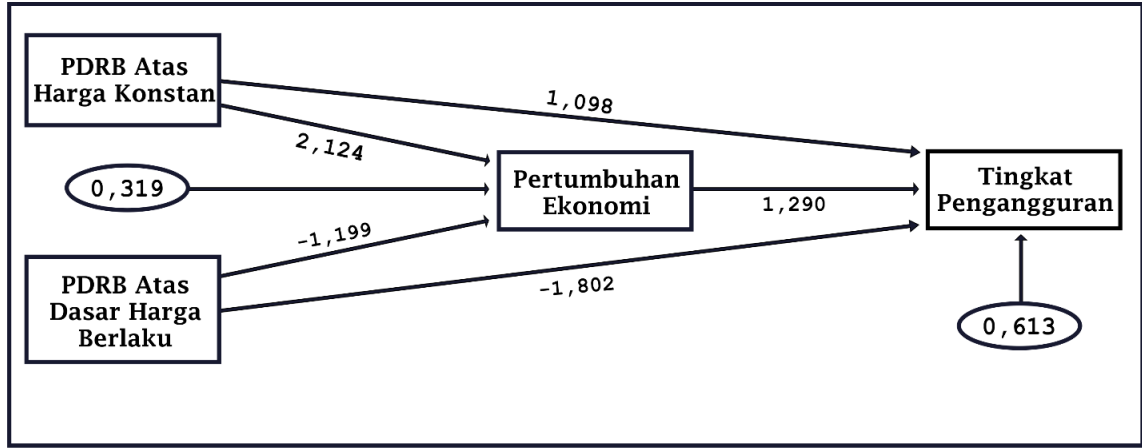

Gambar 2. Path analysis

Dari hasil pengelolaan data tersebut didapatkan persamaan regresi sebagai berikut:

$$
\begin{aligned}
& \hat{Y}_{1}=2,124 X_{1}-1,199 X_{2}+0,319 \\
& \hat{Y}_{2}=1,098 X_{1}-1,802 X_{2}+1,290 Y_{1}+0,613
\end{aligned}
$$

Dari persamaan (1) diketahui variabel coefficient beta PDRB atas harga konstan sebesar 2,124 membuktikan bahwa PDRB harga konstan memberikan perubahan terhadap pertumbuhan ekonomi sebesar 2,124. coefficient beta PDRB atas dasar harga berlaku sebesar (1,199) membuktikan bahwa PDRB atas dasar harga berlaku memberikan perubahan terhadap pertumbuhan ekonomi sebesar $(-1,199)$. Sedangkan error $\left(e_{1}\right)$ diketahui sebesar 0,319.

Dari persamaan (2) diketahui variabel coefficient beta PDRB atas harga konstan sebesar $(-1,098)$ membuktikan bahwa PDRB harga konstan memberikan perubahan terhadap tingkat pengangguran terbuka sebesar (-1,098). Variabel coefficient beta PDRB atas harga dasar harga berlaku sebesar $(-1,802)$ membuktikan bahwa PDRB atas dasar harga berlaku memberikan perubahan terhadap tingkat pengangguran terbuka sebesar $(-1,802)$. Variabel coefficient beta pertumbuhan ekonomi sebesar 1,290 membuktikan bahwa pertumbuhan ekonomi memberikan perubahan terhadap tingkat pengangguran terbuka sebesar 1,290. Sedangkan error $\left(e_{2}\right)$ diketahui sebesar 0,613 . 
3.1. Pengaruh Langsung (Direct Effect). Hasil dari uji t untuk analisis pengaruh langsung antar variabel dapat dilihat pada Tabel 2 .

Tabel 2. Hasil Uji t

\begin{tabular}{|c|c|c|c|c|}
\hline Regresi & $t_{\text {hitung }}$ & $t_{\text {tabel }}$ & Sig & Keterangan \\
\hline$X_{1} \rightarrow Y_{1}$ & 3,335 & 2,131 & 0,005 & Signifikan \\
\hline$X_{2} \rightarrow Y_{1}$ & $-1,882$ & 2,131 & 0,079 & Tidak signifikan \\
\hline$X_{1} \rightarrow Y_{2}$ & 0,656 & 2,145 & 0,523 & Tidak signifikan \\
\hline$X_{2} \rightarrow Y_{2}$ & $-1,277$ & 2,145 & 0,222 & Tidak signifikan \\
\hline$Y_{1} \rightarrow Y_{2}$ & 2,507 & 2,145 & 0,025 & Signifikan \\
\hline
\end{tabular}

Dari tabel 2, dapat disimpulan bahwa dengan uji t diperoleh hasil representasi bahwa Produk Domestik Regional Bruto atas dasar harga konstan yang menunjukkan nilai tambah barang dan jasa yang dihitung menggunakan harga pada tahun tertentu berpengaruh signifikan terhadap pertumbuhan ekonomi, hal ini menunjukkan jika Produk Domestik Regional Bruto atas dasar harga konstan meningkat maka pertumbuhan ekonomi meningkat maka dapat dilihat bahwa Produk Domestik Regional Bruto atas dasar harga konstan berpengaruh positif terhadap pertumbuhan ekonomi. PDRB atas dasar harga berlaku tidak berpengaruh signifikan terhadap pertumbuhan ekonomi, PDRB atas harga konstan tidak berpengaruh signifikan terhadap tingkat pengangguran terbuka, PDRB atas dasar harga berlaku tidak berpengaruh signifikan terhadap tingkat pengangguran terbuka, dan pertumbuhan ekonomi berpengaruh signifikan terhadap tingkat pengangguran terbuka.

\subsection{Pengaruh Tidak Langsung (Indirect Effect).}

3.2.1. Pengaruh PDRB atas harga konstan terhadap tingkat pengangguran terbuka melalui pertumbuhan ekonomi. Pengaruh PDRB atas harga konstan terhadap tingkat pengangguran terbuka melalui pertumbuhan ekonomi dianalisis menggunakan sobel test. Dengan menggunakan perhitungan sobel test diperoleh nilai $z=1,27$, karena nilai $z$ yang diperoleh $1,27<1$, 98 dengan tingkat signifikansi 5\% maka membuktikan bahwa pertumbuhan ekonomi tidak mampu memediasi hubungan pengaruh PDRB atas harga konstan terhadap tingkat pengangguran terbuka.

3.2.2. Pengaruh PDRB atas dasar harga berlaku terhadap tingkat pengangguran terbuka melalui pertumbuhan ekonomi. Pengaruh PDRB atas dasar harga berlaku terhadap tingkat pengangguran terbuka melalui pertumbuhan ekonomi dianalisis menggunakan sobel test. Dengan menggunakan perhitungan sobel test diperoleh nilai $z=1,27$, karena nilai $z$ yang diperoleh $1,27<1,98$ dengan tingkat signifikansi $5 \%$ maka membuktikan bahwa pertumbuhan ekonomi tidak mampu memediasi hubungan pengaruh PDRB atas dasar harga berlaku terhadap tingkat pengangguran terbuka.

\subsection{Pembahasan.}

3.3.1. Pengaruh PDRB terhadap pertumbuhan ekonomi. Penelitian mengenai pengaruh Produk Domestik Regional Bruto (PDRB) terhadap pertumbuhan ekonomi menunjukkan bahwa Produk Domestik Regional Bruto (PDRB) berpengaruh signifikan terhadap pertumbuhan ekonomi atas harga konstan, dan tidak signifikan terhadap pertumbuhan atas dasar harga berlaku.

3.3.2. Pengaruh pertumbuhan ekonomi terhadap tingkat pengangguran terbuka. Hasil analisis data dengan path analysis menunjukkan bahwa selama tahun 2013-2015, pertumbuhan ekonomi berpengaruh positif terhadap tingkat pengangguran terbuka di Provinsi DKI Jakarta. Hal ini berarti semakin naiknya pertumbuhan ekonomi akan meningkatkan tingkat pengangguran terbuka dan semakin turun pertumbuhan ekonomi akan menurunkan tingkat pengangguran terbuka.

Secara teori, jika pertumbuhan ekonomi meningkat maka diharapkan dapat menyerap tenaga kerja, sehingga dapat merendahkan tingkat pengangguran dalam artian pertumbuhan 
ekonomi berpengaruh negatif terhadap tingkat pengangguran. Namun, hasil penelitian menunjukkan bahwa pertumbuhan ekonomi di Provinsi DKI Jakarta berpengaruh positif terhadap tingkat pengangguran. Hal ini dapat dikarenakan pertumbuhan ekonomi hanya berdasarkan angka-angka makro seperti tingkat inflasi yang terkendali, Produk Domestik Regional Bruto (PDRB) yang meningkat, nilai tukar mata uang yang rendah, dan lain sebagainya, sedangkan sektor riil masyarakat khususnya Usaha Kecil dan Menengah (UKM) kurang berkembang dan berdaya sehingga kurang atau tidak dapat menyerap jumlah pengangguran. Selain itu, pertumbuhan ekonomi yang tidak dibarengi dengan kapasitas produksi dapat menyebabkan tingkat pengangguran meningkat seiring dengan pertumbuhan ekonomi. Pertumbuhan ekonomi yang meningkat ini berorientasi pada padat modal, dimana kegiatan produksi memacu output dan menghasilkan pendapatan yang meningkat lebih diutamakan ketimbang pertumbuhan ekonomi yang berorientasi pada padat karya.

Provinsi DKI Jakarta memiliki tingkat urbanisasi yang tinggi, jika urbanisasi tidak dapat terkendali dengan baik maka akan berdampak negatif terhadap perekonomian masyarakat. Salah satu dampak yang terjadi jika urbanisasi tidak terkendali yaitu meningkatnya angka pengangguran. Pertumbuhan ekonomi di Provinsi DKI Jakarta yang cukup pesat tidak dibarengi dengan pemerataan di setiap sector wilayah menyebabkan tingkat pengangguran yang cukup tinggi.

\section{Simpulan}

Berdasarkan pembahasan sebelumnya, maka dapat disimpulkan sebagai berikut.

(1) Produk Domestik Regional Bruto (PDRB) atas harga konstan berpengaruh positif dan signifikan dengan pertumbuhan ekonomi, hal ini berarti semakin besar PDRB atas harga konstan maka akan diikuti oleh semakin tinggi laju pertumbuhan ekonomi

(2) Produk Domestik Regional Bruto (PDRB) atas dasar harga berlaku berpengaruh negatif dan tidak signifikan dengan pertumbuhan ekonomi.

(3) Produk Domestik Regional Bruto (PDRB) atas harga konstan berpengaruh positif dan tidak signifikan dengan tingkat pengangguran terbuka.

(4) Produk Domestik Regional Bruto (PDRB) atas dasar harga berlaku berpengaruh negatif dan tidak signifikan dengan tingkat pengangguran terbuka.

(5) Pertumbuhan ekonomi berpengaruh positif dan signifikan terhadap tingkat pengangguran terbuka, hal ini berarti semakin tinggi laju pertumbuhan ekonomi maka akan diikuti dengan semakin tinggi angka pengangguran terbuka.

(6) Pertumbuhan ekonomi bukan merupakan variabel mediasi dalam PDRB harga konstan dan PDRB atas dasar harga berlaku terhadap tingkat pengangguran terbuka.

\section{Daftar Pustaka}

[1] Hamzah Ardi, Analisis Pengaruh PAD, DAU, DAK, dan Belanja Pembangunan terhadap Pertumbuhan Ekonomi,Kemiskinan, dan Pengangguran:Pendekatan Analisis Jalur, Jurnal Akuntansi dan Keuangan Indonesia, Vol.4, No. 2, Desember 2007, hal. 211-228.

[2] Alghofari, Farid, 2010, Analisis Tingkat Pengangguran di Indonesia Tahun 1980-2007.

[3] Agustin, Linda, 2011, Pengaruh Langsung dan Tidak Langsung Biaya Perawatan, Fasilitas, Lokasi dan Pelayanan terhadap Loyalitas Melalui Kepuasan Pasien, Jurnal Sains dan Bisnis Indonesia, Vol. I, No. 1, September 2011, Hal 151-173.

[4] Kurniawan, R. C., 2013, Analisis PDRB, UMK, dan Inflasi terhadap Tingkat Pengangguran Terbuka di Kota Malang Tahun 1980-2011.

[5] Himawan, et al. 2016, Pengaruh Produk Domestik Regional Bruto (PDRB) terhadap Tingkat Kemiskinan di Kota Manado (Tahun 2005-2014), Jurnal Berkala Ilmiah Efisiens,Volume 16 No. 03.

[6] Parwata, I Made et al, 2016, Pengaruh Produk Domestik Regional Bruto (PDRB) dan Tingkat Pengangguran Terbuka terhadap Tingkat Kemiskinan, E-Journal Bisma Universitas Pendidikan Ganesha : Jurusan Manajemen. 
